\title{
Research on Teaching Reform of Computer Basic Course in Higher Vocational Colleges
}

\author{
Dongjie Jiao ${ }^{1, a^{*}}$ and Sujuan $\mathrm{Shi}^{2, \mathrm{~b}}$ \\ ${ }^{1}$ Luohe Medical College, Luohe 462002, China \\ ${ }^{2}$ Luohe Medical College, Luohe 462002, China \\ a Jiaodongjie1999@163.com, b28289909@qq.com
}

Keyword: Necessity; Problem; Operational

\begin{abstract}
Relative to the general higher education in terms of training academic talents, Higher vocational education emphasizes the cultivation of higher technology applied talents, But because the quality of education is not high, so the basic courses of vocational courses only by the older textbooks for lectures, students cannot do the combination of tutorials and practice. In order to correspond to the national policy, the higher vocational computer basic course has carried on the related teaching reform, causes the student to unify the theory and the practice, and applies the learning thing to the practice.
\end{abstract}

\section{Introduction}

With the continuous development of society, the computer has become a real life in the common skills. So many college computer science courses were also carried out, but because of the course practical ability is stronger, but only starting from the base, so a lot of computer to major students ' practice ability than people who are not professional, based on the situation, the State reform of computer basic course teaching in higher vocational education.

\section{The Necessity of Teaching Reform of Basic Computer Course in Higher Vocational Education}

The Ministry of education of higher education in the syllabus clearly, At present, the major of the school has set up the basic course of computer, Especially non-computer professional basic courses. However, due to the rapid development of social information, along with the employment pressure to find a larger job, so the basic curriculum of teaching tasks and teaching content is constantly changing, and higher vocational education is based on practical ability-based education [1], It is necessary to distinguish this from other courses on the basis of this course. It is because of this reality, it is necessary to reform the basic course of computer science in higher vocational colleges.

Because of the higher vocational students have the necessary theoretical knowledge and scientific and cultural foundation, master backbone technology, focusing on the practical application. So the teaching reform of higher vocational computer education should be employment to the development of education combined with the direction of production [2], So that vocational colleges as a resource development center.

\section{The Problems of Computer Basic Course in Higher Vocational Education}

Newborn for the Computer Operation of the Basic Deviation. Resource imbalance, infrastructure imbalance is a common problem, With the gradual development of home computers, Advanced computers have no need to start from scratch, But because the junior high school teaching resources level is uneven, coupled with some areas do not attach importance to junior high school computer courses, Computer courses are not carried out, so there is a large difference in the level of computer based freshmen enrollment [3]. 
Due to regional differences, some freshmen will not be based on computer before admission, So there is no concept of basic theory. Some students in time is not a computer professional students, but the basic operation of the computer has been very skilled. This imbalance leads the teacher to not be able to teach well [4].And then is the computer professional students are the basic operational ability, So if the teacher re operation will waste the time of students, So these contradictions need to be teaching reform.

Not Closely the Specialty Setting and Academic. Each higher vocational education has its own unique curriculum, For computer and non computer majors, It is a serious problem that the combination of specialty setting and academic specialty is not close. Computer technology has appeared in various disciplines, Different subjects have different requirements on computer courses. At present, the basis of our computer is more books on the theory, and the above theoretical operations are a few years ago, there is no practical [5].If the professional settings and students can not be closely integrated with the professional, students will feel that they do not learn something practical, so that students have a certain psychological conflict, so there is no way to do a combination of professional and practical. This will also increase the students' negative attitude, serious will also affect whether the students can get a good job.

Now the status quo is the computer professional students in the daily class, the teacher attaches importance to the theory, curriculum arrangements in addition to the theory is a compulsory course for College Students, Such professional settings and academic professional unreasonable. Non computer professional students weekly computer class is just the form, the teacher can not teach anything, and their own professional and computer combination is not close.

Students' Poor Operability. We often see some of this class, the teacher in front of the tireless talk about slides, while students are playing under the phone, This class is very common in Higher Vocational Education. But it also reflects a problem, which will lead to poor students' ability to operate. When students in the basic courses, because teachers are explained according to the content of the textbooks, there are some maneuverability theory, and students can only remember not to operate on the theory, do not know their own shortcomings and the insufficiency where there is no way corresponding to the change. This vicious cycle will only make the professional students more operable. Non-professional students even so, Non-professional students of the computer class is a large classroom, a lot of people together, the teacher is simply explain the theory again, even if the class can understand, no practice or not. All of these will lead to poor operation. As the teaching model is not complete update, many teachers still use the teacher to take the initiative to speak, students are listening to the situation so that even if the teacher talked about in the classroom, the autonomy of students can not be mobilized.

The Professional Quality of the Teacher is Low. With the continuous development of society, the society is more and more demanding for the computer ability. But a lot of teachers in the teaching is just to move the textbook, so there is no way to do the unity of practice and theory. Teachers do not keep pace with the times, but in accordance with the theory to give lectures to the students, and some do not update the practice, these are the reasons for the low professional quality of Teachers. Higher vocational teachers in teaching because of the students' level is not high, Stay in the status quo not to learn, With the development of practice, their professional quality will be lower and lower

The teacher and other positions are different, when the operation of the computer only needs to master the most basic operation can not, what needs to be updated, the professional quality that will make the teacher stop not before, and even stop.

Incomplete Infrastructure Construction. Some schools because of the computer professional is relatively small, other professionals do not attach importance to the computer, resulting in fewer computer rooms. Because the infrastructure is not complete, so the school will reduce the students' class time. Students can not do the combination of practice and theory, Such a situation will also delay the operation of the computer for students, so this is why the reform of Higher Vocational Computer Courses. 
There are Many Contradictions between Short Teaching Hours and Teaching Contents. In University, Students should have their own autonomy, this will lead to shorter hours, But in computer science, students should be proficient in computer operation, But in computer science, students should be proficient in computer operation, Involving a wider range, So there is a short period of time, but the content of teaching more contradictions. Such students may only see once a week teacher, Originally operating capacity is poor, coupled with a long time interval, So the teacher must speed up the progress of the class in order to complete the progress, And students because the content is more strange will feel the teacher's course faster, there is no way to keep up with the curriculum, this contradiction is not conducive to student learning.

\section{Suggestions on Teaching Reform of Basic Computer Course in Higher Vocational Education}

Hierarchical Teaching in Higher Vocational Colleges. Because of the different levels of computer literacy, If a teacher only considers the basis of a part of the students, the other students will be ignored, So the teacher in the computer based teaching can be considered to study the hierarchical teaching, Based on the better students to learn some of the key points of the operation, increase the operability of students after graduation ${ }^{[6]}$.For students with weak foundation, teachers should start from the basis of teaching, so as to reduce this part of the students' sense of inferiority, improve students' interest in learning.

After the students have been stratified, the teacher should also be stratified by the practice of the students, Students who have a good degree are more difficult to operate, Students who are weak in learning pay attention to the theory and foundation in practice. The stratified teaching can improve the teaching quality of teachers and promote the teaching reform of computer basic courses in Higher Vocational Colleges.

Combining Students' Professional and Industry. Because of the continuous development of society, Computers are gradually penetrating into other industries, This will not only ensure that students in the school to complete the basic operation of the computer, It also provides a practical basis for the development of computer basic course teaching ${ }^{[7]}$.Higher vocational computer professional is not only to master the computer foundation, the more important purpose is to operate the computer. Therefore, the computer is also an important cornerstone of students' professional knowledge learning and Application, This also requires higher vocational colleges to be able to do the computer foundation is not simply the basis of learning theory, And the students professional and industry integration.

School Science Set up Teaching Content. College computer basic course teaching is a course which provides theoretical basis and training for non computer majors in Colleges and Universities, During the study period, Students should learn the most basic computer applications, the use of operating software and office software ${ }^{[8]}$. However, in the course of teaching, teachers pay too much attention to the explanation of theoretical knowledge, but ignore the practical operation of students. So curriculum reform should increase the opportunity for students to practice, Comprehensive theory of the operation, in the operation to find their own shortcomings and correct ${ }^{[9]}$.Practice is the truth. Only the students themselves will have a better understanding of knowledge.

Flexible Choice of Teaching Methods. Higher vocational students have different interests and hobbies before entering the University, So the teacher in teaching should be individualized. The students who have better mastery of the theory pay more attention to the actual operation, For the weak foundation of the students should be encouraged to stimulate the enthusiasm of students, so that students learn.

Make different goals for different learning, Because of the difference between the basic and cognitive ability,Can not expect all students to work on the computer, Find out the advantages of students in the guidance to help students improve.

Flexible choice of teaching methods can increase the quality of teaching, Create a better learning 
atmosphere, Lay a good foundation for students to learn computer.

Strengthen the Construction of Teaching Staff, Improve the Quality of Teachers. Now the society is developing rapidly, Higher vocational colleges are facing a new situation, With the continuous development of computer technology, In order to better promote the teaching reform of computer basic courses in higher vocational colleges, we should strengthen the construction of teachers team ${ }^{[10]}$ In order to develop a strong team of teachers, higher vocational schools should train teachers regularly, Increasing the teacher's professional quality, improve the professional knowledge of Teachers. On the other hand, teachers are encouraged to continue their studies at school, Can set a certain reward system for teachers who have been learning, so that the active teachers to drive other teachers and students, to strengthen the construction of teaching staff. The strength of the teaching staff of the computer basic course teaching reform plays a role in promoting.

Schools should Strengthen Infrastructure Construction. Schools should build supporting infrastructure, so that students can increase the learning experience. Schools should increase the construction of computer room facilities, and strive to achieve more opportunities for students to practice. And the school can recommend a good number of campus website ${ }^{[11]}$, Create a better learning atmosphere. The school should regularly check the electronic equipment to ensure that all the equipment can run normally.

The reform of higher vocational computer teaching needs the cooperation of the school, teachers and students, The teacher should choose the teaching method flexibly in the teaching process, Do teach each other. Can not be excessive blow students' learning enthusiasm, For students to find problems and help correct. The teacher can not die in the course of teaching, Attention should be paid to the combination of theory and Practice. Help students to improve their knowledge and skills. should increase their enthusiasm in learning, Improve learning interest. Students do not understand the problems to communicate with the teacher and correct in time. Learning should be active in the learning process, Encourage students to put forward different views and teachers should debate.

In the process of teaching, the school should pay attention not only to the cultivation of students' operating skills, but also to cultivate students' professional quality, Strengthen professional consciousness. Such mutual help can promote the teaching reform of Higher Vocational Computer Basic Courses.

\section{Reference:}

[1] H.Suo, Higher vocational computer information management professional personnel training mode [J].Vocational \& Technical Education Forum.2012 (17).94-95.

[2] L.Xu, On the teaching methods of computer web course in Higher Vocational Colleges. [J].Intelligence. 2015 (28). 26-26.

[3] J.P.Tian, Research on the Reform of Public Education in Higher Vocational Colleges [J].Continue Education Research.2014(8).112-113.

[4] J.Wang,H.Y.Zhang. and P.Li, Research on the reform of curriculum system and teaching method of computer specialty in Higher Vocational Education.[J].Asia-Pacific Education.2016.(3).141.

[5] X.B.Zhang,J.Peng,.A study on the blended teaching model of higher vocational college computer application ability[J].Science and Technology.2016.26(17).199,201.

[6] X.LHu, On the teaching reform trend of computer training course in Higher Vocational CollegesJ].Telecom World..2015.(24).292-293.

[7] H.Chen, C.He, Research on the optimization strategy of employment oriented Higher Vocational Computer Teaching Mode[J].Journal of Hunan Post and Telecommunication College.2015(2).117-119. 
[8] J.C.Li, Discussion on employment oriented Higher Vocational Computer Teaching Reform[J].Knowledge Economy.2015(10).125.

[9] Z.Nie, Teaching reform and practice of computer common course in Higher Vocational Colleges from the perspective of Computational Thinking[J]Computer Education.2014(7).20-23,29.

[10]S.Y.Dong, Discussion on the construction of computer application technology specialty in Higher Vocational Education[J].Heilongjiang Science.2015(18).106-106,109.

[11] Y.Q.Deng, Research on the innovation of computer experiment teaching in Higher Vocational Colleges[J].JUANZONG,2016.6(2).618. 